\title{
Engineering model of traffic and transportation safety with pattern of cooperation between sustainable region in Bogor
}

\author{
Syaiful ${ }^{1, *}$ \\ ${ }^{1}$ Ibn Khaldun University, Civil Engineering Departement, 16162 Bogor, Indonesia
}

\begin{abstract}
Bogor and Bogor district is the buffer zone of the capital Jakarta Special Capital Region. Bogor city as the city has also become a pilot implementation of the one way system (SSA) and the Contra Flow pilot system, the system open and closed area of Puncak, Bogor. If examined more deeply traffic flow and patterns of population movement is very diverse city. The diversity of travel of the city resulted in the number of people who pass through the region is also increasingly diverse. Population mobility infrastructure also requires adequate transportation. Adequate facilities and infrastructure that meet the criteria as it is safe, convenient and affordable for the community. If explored further that the more the number of vehicles crossing the city of Bogor and the types of vehicles also increased. This increase raises the issue in the field of transport. The problem varies according to the level of speed, volume and density of vehicles resulted in a noise due to exhaust gas. Highway safety is very important to address reducing the risk of death and permanent disability is experienced riders of motor vehicle and highway users.
\end{abstract}

\section{Background of the problem}

Bogor city and Bogor district is the buffer area of Jakarta Capital City Special Capital Region. Bogor City and Bogor regency are not directly adjacent to Jakarta, but the city of Bogor is a transit area and the residents of Jakarta and surrounding areas to rest area. Bogor City is also a pilot as a city of application of one-way system (SSA) and pilot Contra Flow system, open close system in the area of Puncak Bogor. If studied more deeply the flow of traffic and patterns of urban population movement is very diverse. The diversity of the city's journeys has resulted in a growing number of people passing through the area [1]. Population mobility also requires adequate transportation facilities and infrastructure. Sufficient facilities and infrastructure that meet the criteria such as safe, convenient and affordable for the community [2]. If further examined that the more days the number of vehicles that cross the city of Bogor and the type of vehicle is also increasing. This increase poses problems in the field of transportation. The problem varies according to the speed,

\footnotetext{
*Corresponding author: syaiful@fft.uika-bogor.ac.id
} 
volume and density of the vehicle resulting in noise caused by the flue gas. Noise is generated by the sound of motor vehicle engine and the remaining sound due to the reflection of objects around it [3].

While the relationship between Speed-Volume-Density is the relationship between volume (q) and density ( $\mathrm{k}$ ) is called the fundamental diagram for traffic, or the q-k curve. Empirical studies show that the rising density of the stream first increases and reaches its maximum and then turns down, but there is some conflicting evidence regarding the exact shape of the curve. The shape and calibration of such relationships is important, as they provide the basis for the selection of measures of effectiveness and definition of the rangeof-service range for the expressway segment [4].

Influence other than those associated with the vehicle such as wind speed, temperature, humidity is very small then ignored the noise [5]. Noise generated by influential vehicles from long-term residents in a housing complex and deeply disturbed if they stay more than a year [6]. The noise acceleration depends on the three basic elements of the traffic flow, ie, the driver, the road, and the traffic conditions $[7,8]$. Noise in question is the sound of motor vehicles simultaneously on the highway, generally this noise is related to the inconvenience of listeners nearby. Noise can be regarded as a vehicle speed interference from a uniform speed and can be identified as a measurement of the smooth flow of traffic. The predicted number of motor vehicles based on the noise level is influenced by the average speed, the passing vehicle type and the noise damping factor, the method used is fuzzy prediction system with $8 \%$ error rate [9 - 15].

\section{Purpose of the study}

The purpose of this research are:

Obtain road safety level Pajajaran Bogor city on the path of SSA (One Way System) based on the matrix of destination.

\section{The frame of thought}

The modeling of this research approach is to examine how much the effect of motor vehicle traffic condition has impacted the activity of road users either on straight road, turn road, road with smooth surface (paved road), road with rough surface (concrete road/rigid pavement) to safety riding due to motor vehicle noise is based on speed [2, 15]. In this research is presented in the form of a frame of thought as below (Figure 1); 


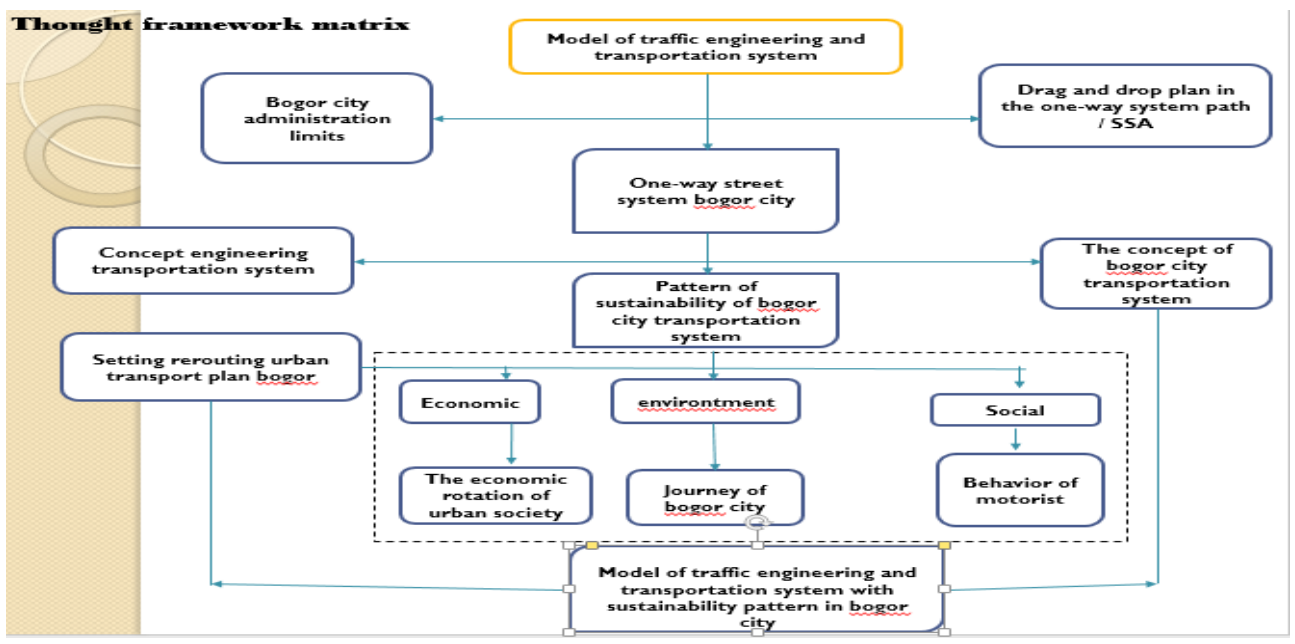

Fig. 1. Thougt framework matrix.

\section{Problem Formulation}

The formulation of the problem in the draft proposed research proposal of this dissertation plan is considered very complex, important and needs to be investigated. The existence of motor vehicles in the city of Bogor and Bogor district increasingly increasing and increasing [1]. The increase in the number of motor vehicles can no longer be prevented, due to various social factors that follow, including the easy to get motor vehicles such as motor credits and cars [2]. So also supported the existence of Mall/Supermarket growing in every corner of the city. The development of shopping facilities, public spaces and pedestrians, schools and places of worship and housing is a factor that triggers the increase of people's activities in daily life [3]. Preparation of research on traffic engineering model and transportation system with sustainable inter-regional cooperation pattern in Bogor city is to produce congestion model, transportation safety and noise level. The passing vehicles are classified as non-motorized vehicles (KTB), motorcycles (SPM), private car transport (AMP), freight cars (MAB) and passenger cars (MAP), as well as heavy transport vehicles (KAB). Several studies have shown that problems with congestion, transport safety and sustained traffic noise levels have not been satisfactorily answered or split.

Observing the facts and phenomenon above writer attempt to arrange research about. This is what makes researchers want to examine more about the model of noise levels caused by motor vehicles, the influence of motor vehicles on traffic congestion, noise and safety, especially in the city of Bogor. How much influence the public per capita opinion and performance patterns of urban communities. The influence of the behavior of passengers on public transport and road users and how motor vehicle users perform. And how big is the level of user annoyance that reflects the level of public awareness in addressing the circumstances surrounding the presence of highway traffic. Public disturbance to the noise caused by motor vehicle traffic in connection with daily activities how big.

The results of the equations obtained in this study are expected to be quantitative and qualitative in nature with field data taking and referring to the correct statistical methods. The result forecast is a model of traffic engineering and transportation system with sustainable inter-regional cooperation in Bogor city. 


\section{Hypothesis}

Hypothesis testing is proposed is traffic congestion, driving safety and influence of motor vehicle noise level.

Highway traffic congestion level against noise generated by motor vehicles. The level of transport safety to noise affected by the number of vehicles.

\section{Data Collection Method}

In this research conducted various data collection methods in the field such as data retrieval by interview survey method, secondary data retrieval method at SSA location.

\section{Methods of data analysis}

Data processing is carried out in several stages, namely for data taken directly in the field such as speed, volume and traffic density of motor vehicles using fuzzy Logic Method [8] and expert system model of ISM Professional [9].

In the data transport safety data taken secondary data available in the police and data in hospitals with secondary data processing.

For sampling method using the number of respondents according to Slovin is by the formula:

$$
\begin{aligned}
& n i=\frac{N i}{N} \times n \\
& n=\frac{N}{1+N(e)^{2}}
\end{aligned}
$$

$\mathrm{N}=$ sample size

$\mathrm{N}=$ population size

$\mathrm{E}=$ standard error $(5 \%-8 \%)$

$\mathrm{ni}=$ sample size strata $\mathrm{i}$

$\mathrm{Ni}=$ population size strata $\mathrm{i}$

In noise model taking.

Leq

$$
=10 \log \left(\sum n i x 10^{\mathrm{Li} / 10}\right) / \mathrm{N}
$$

That is:

$\mathrm{N}=$ number of observations

$n i=$ number of observations that cost L [11].

\section{Research Design}

The following submitted research has been and will be implemented for 12 months in the city of Bogor (Figure 2); 


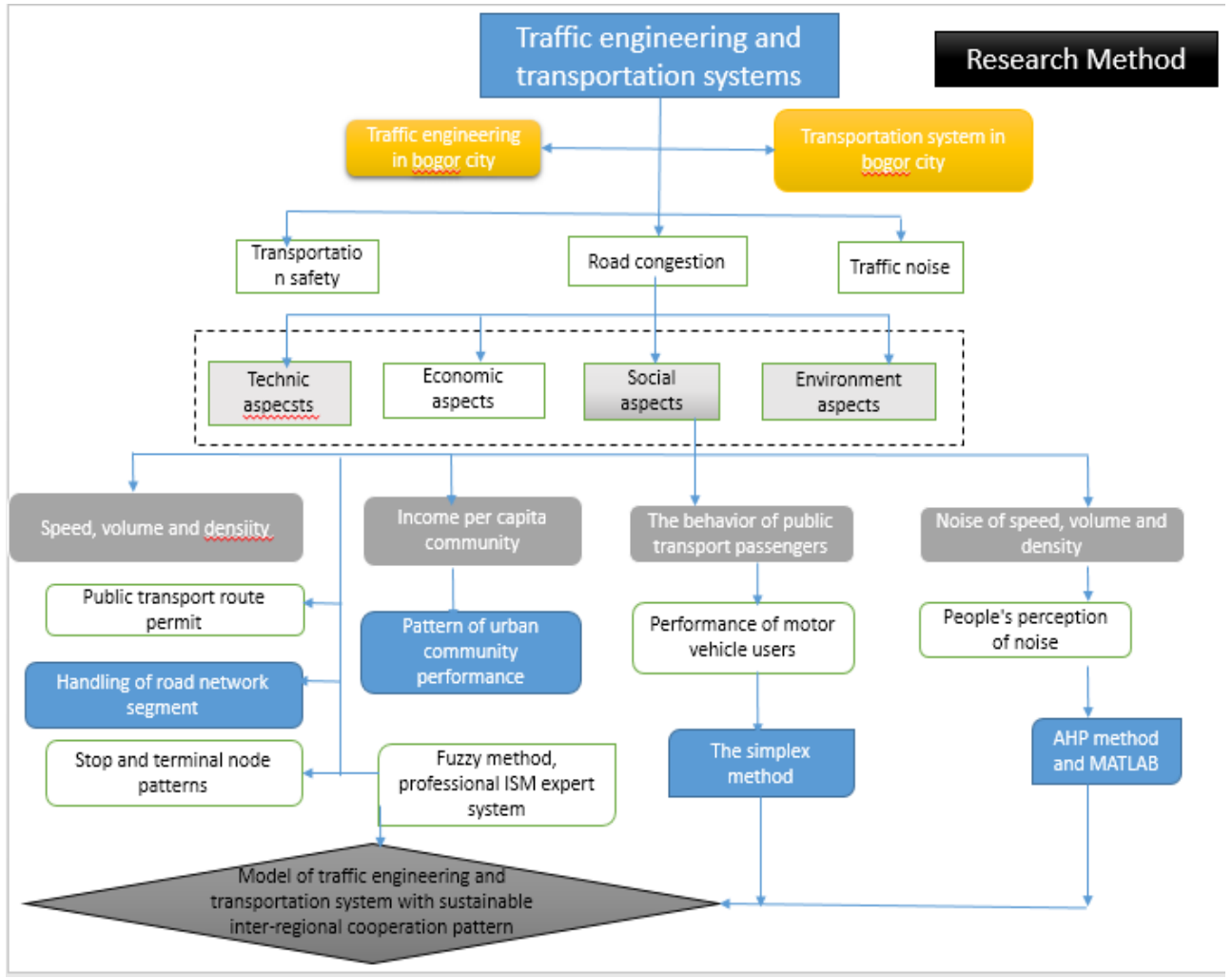

Fig. 2. Research method matrix

\section{Place and time of research}

This research takes place in Pajajaran street with One Way System of Bogor city and Bogor district. The study was conducted for 12 months ie from January 2017 to December 2017. Currently the research is still ongoing. However, as an illustration has been able to image data used to be processed as a preliminary material to plan something about the matrix of destination included secondary data prepared by the traffic service traffic and Bogor city transportation (Figure 3, Figure 4, Figure 5, Figure 6, Figure 7 and Figure 8);

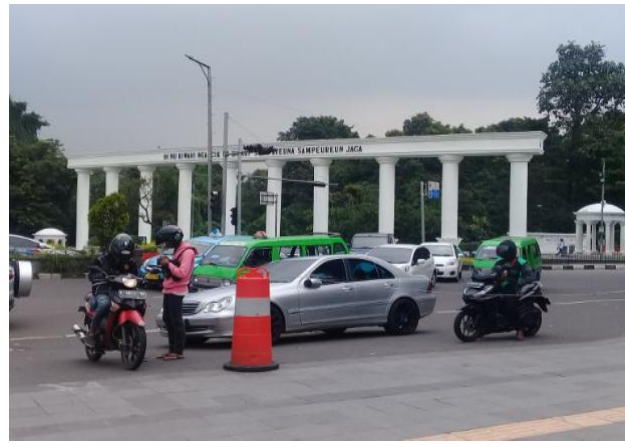

Fig. 3. Junction crossing monument of kujang

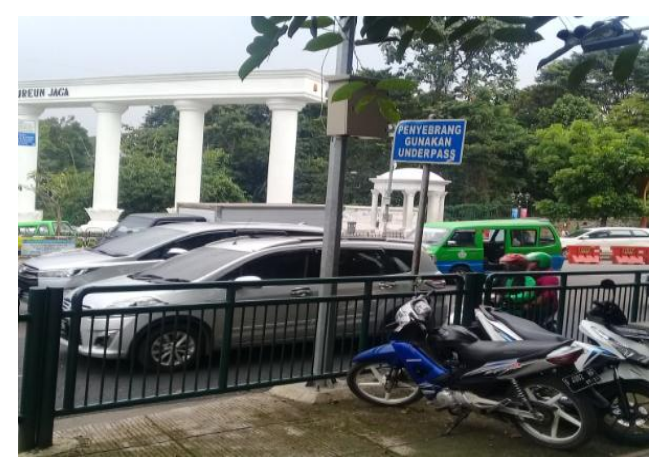

Fig.4.Clutter around traffic light monument kujang 


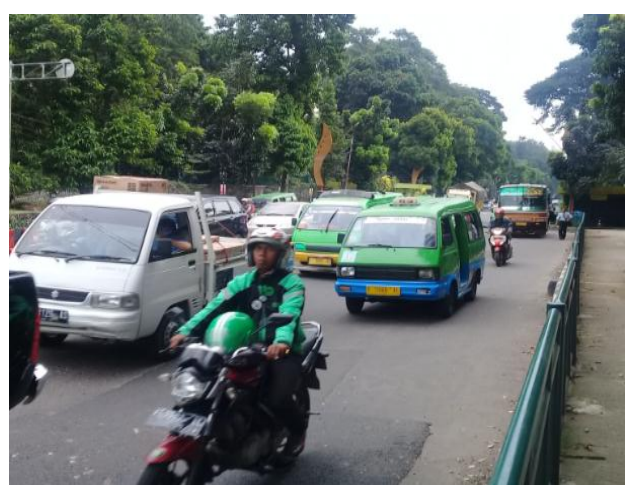

Fig. 5. Monument of kujang bogor city

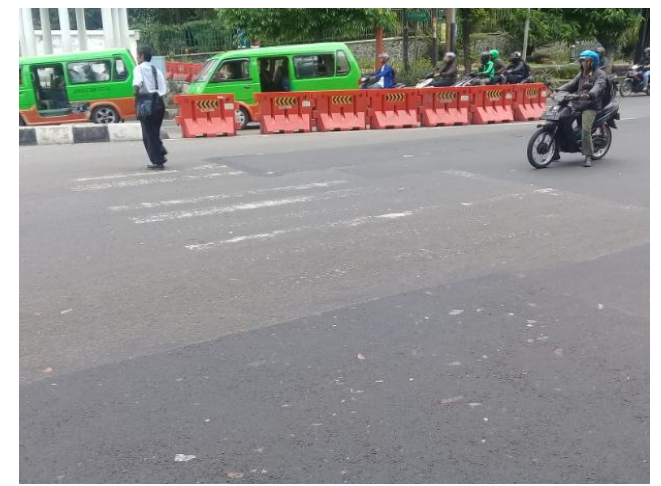

Fig. 6. The faded zebra cross

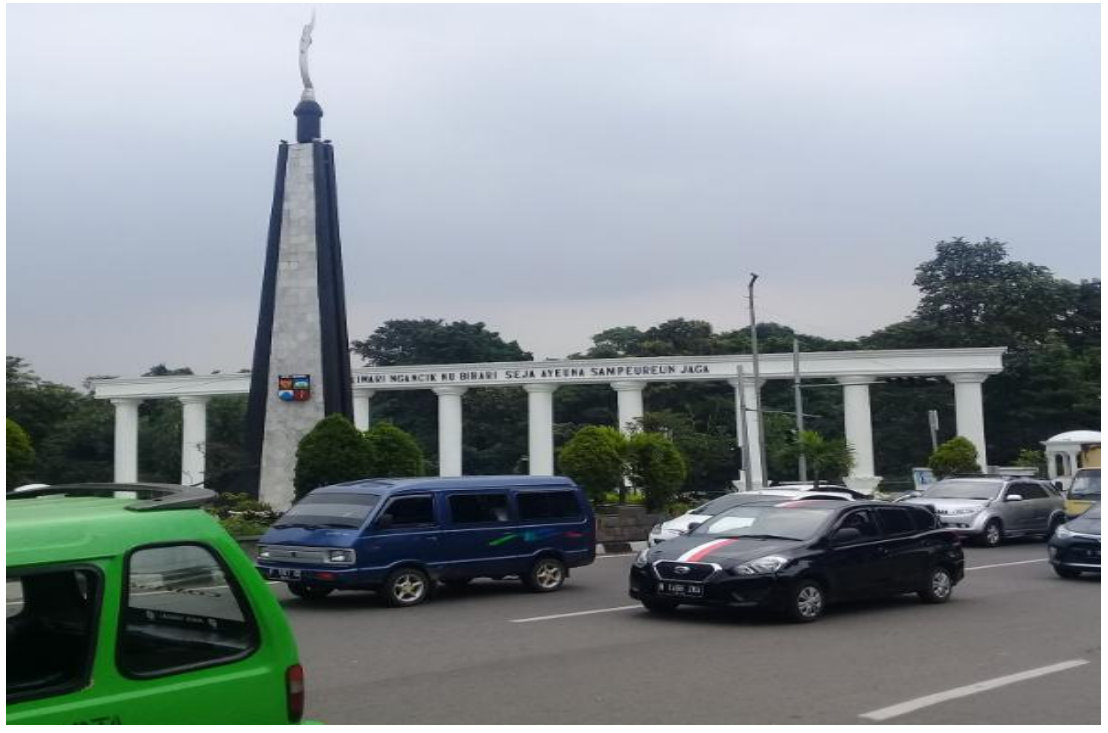

Fig. 7. The New symbol of the monument kujang city bogor

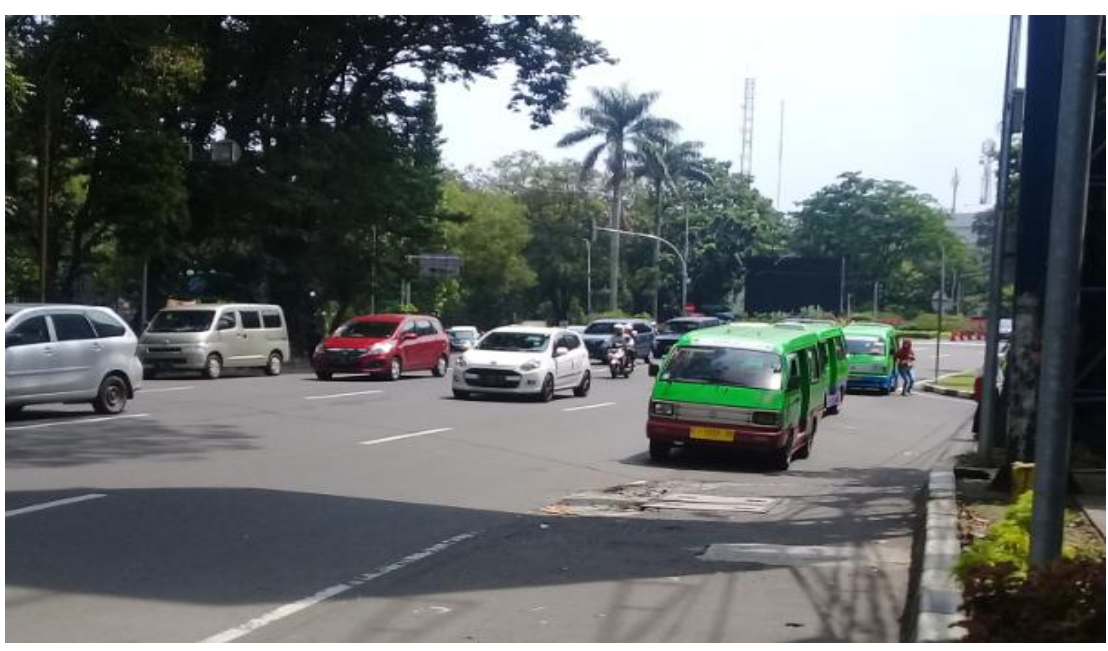

Fig. 8. Pajajaran street in one way system in city bogor 


\section{Results of calculation of SSA path movement in Bogor city}

The model of the movement generation is intended to produce a model of the relationship between the number of movements with the socio-economic characteristics of the perpetrators of the movement leading to and to a zone. This modeling is very necessary to know how big the movement that occurred in the future.

On modeling the rise of movement of motor vehicles and citizens using zone based movements. For Pajajaran road including subdistrict zone Bogor East urban village bogor based on urban village zone. The consideration of using the zone based on the village is based on the things that affect it, among others:

1) Knowing how much the movement generates (production and attraction of movement) for each village.

2) Analyze the social and economic level characteristics of the research area based on the data input from the village.

Based on the rise and based on the matrix of origin of the movement of the community in urban Bogor District can be observed more thoroughly. Similarly, the level of socioeconomic characteristics of perpetrators of the movement in the region does affect the magnitude of the movement of the urban population. Getting the characteristics of the rate of urban population movement is obtained based on the survey, as for the survey is the survey of individual income, family dependents and ownership of homes and motor vehicles:

1) Individual income (a1)

2) How many family dependents (a2)

3) House ownership status (a3)

4) Status of ownership of motor vehicles (a4)

5) Travel duration at SSA location (a5)

For free variable is the amount of movement of urban community in research location that is SSA for every perpetrator of movement in time unit that is $(\mathrm{y})$.

The process of modeling the rise of movement (production and pull) begins by looking at the correlation of the independent variable and the independent variable of the movement. The greater the correlation between these variables indicates that socioeconomic characteristics greatly influence the number of movements. And vice versa, the smaller the correlation then the relationship between these variables do not affect each other. The correlation between independent and non-free variable of Bogor city movement can be seen in (Table 1 and Table 2);

Table 1. The relationship of independent variables with free variable pattern of urban community movement

\begin{tabular}{|c|c|c|c|c|c|c|}
\hline Relationship & $\mathbf{y}$ & $\mathbf{a 1}$ & $\mathbf{a 2}$ & $\mathbf{a 3}$ & $\mathbf{a 4}$ & $\mathbf{a 5}$ \\
\hline $\mathbf{y}$ & 1 & & & & & \\
\hline $\mathbf{a 1}$ & 0,24329 & 1 & & & & \\
\hline $\mathbf{a 2}$ & 0,32547 & 0,04365 & 1 & & & \\
\hline $\mathbf{a 3}$ & 0,04421 & 0,05492 & 0,00758 & 1 & & \\
\hline $\mathbf{a 4}$ & 0,04342 & $-0,07611$ & 0,00421 & 0,00163 & 1 & \\
\hline $\mathbf{a 5}$ & 0,03121 & 0,006542 & $-0,00987$ & 0,00729 & 0,00321 & 1 \\
\hline
\end{tabular}

Source: Processing using expert system of Professional ISM [9] 
Table 2. Relationship of independent variables with free variable pattern of urban community movement

\begin{tabular}{|c|c|c|c|c|c|c|}
\hline Relationship & $\mathbf{y}$ & $\mathbf{a 1}$ & $\mathbf{a 2}$ & $\mathbf{a 3}$ & $\mathbf{a 4}$ & $\mathbf{a 5}$ \\
\hline $\mathbf{y}$ & 1 & & & & & \\
\hline $\mathbf{a 1}$ & 0,03242 & 1 & & & & \\
\hline $\mathbf{a 2}$ & 0,03215 & 0,64321 & 1 & & & \\
\hline $\mathbf{a 3}$ & $-0,06432$ & 0,06576 & $-0,09643$ & 1 & & \\
\hline $\mathbf{a 4}$ & 0,03238 & $-0,04333$ & 0,076512 & 0,02198 & 1 & \\
\hline $\mathbf{a 5}$ & 0,07432 & 0,04365 & 0,003265 & 0,04365 & 0,032347 & 1 \\
\hline
\end{tabular}

Source: Processing using expert system of Professional ISM [9]

Table 1 means that all positive-valued variables have an effect on the pattern of community movement of Bogor city such as individual income of 0.24329 , family dependent of 0.32547 , home ownership of 0.04421 , ownership of motor vehicle 0,04342 and length of time in passing SSA equal to 0.03121 . Table 2 shows that the variables that influence the pull of urban movement are each of the family dependents of 0.04365 , the home ownership is 0.00758 , the motor vehicle ownership is 0.00163 and the length of time in the passing of the SSA is 0.00321 .

For the movement of urban community due to tension with free variable is negative value of each negative value that is home ownership of $\mathbf{- 0 . 0 7 6 1 1}$ and the length of time passing on the road SSA $\mathbf{- 0 . 0 0 9 8 7}$. This means that there is a negative value relationship is there is no relationship of mutual influence between positive values on the pattern of movement of the city of Bogor today.

\section{Conclusions}

The tentative conclusions of this study are:

1) There is a very close relationship between the number of tugs of the study area around the SSA line with safety in transport.

2) There is no correlation between the number of Bogor city community awakening to home ownership and time taken when passing on SSA road.

\section{References}

1. Bappeda K.B, Bogor dalam angka, 2, hal. 45-46 (2014) (Indonesian)

2. Directorate General of Highways, 1, hal. 32-33, Jakarta (1997) (Indonesian)

3. E. R. Purnomo, J.M.T, 4, hal. 90-92, Yogyakarta (1997) (Indonesian)

4. L.E. Haefner, M-S. Li, L.A. Porello, CTRE, Semisequentennial transportation conference proceedings, 1, pp 11-12, Ames, Iowa (1996)

5. Kep. M.N.L.H, 48, pp. 7-9, Jakarta (1996) (Indonesian)

6. L.P. Bangun, I.M. Kamil, I.B.A. Putra, Kebisingan lalu lintas dan hubungannya dengan tingkat ketergantungan masyarakat, 1, F.T.S.L, hal. EH-2-EH-11, Bandung (2009) (Indonesian) 
7. L.E. Haener, Preliminary data collection and analysis for traffic flow management on a freeway corridor, D. Civil Engineering, Washington University, St. Louis (1996)

8. H. Martono, Wijayadi, The health effects of environmental noise other than hearing loss, P.A. Number 3311, JN 7845, Australia (2004)

9. N.M.F. Saputra, T.Pynkyawati, J.O.I.T.N, 4, hal. Reka karsa-1- 10, Bandung (2014) (Indonesian)

10. Resmana, J.T.E, 1, hal. 23-24, Universitas Kristen Petra, Surabaya, (1999) (Indonesian)

11. R. Setiawan, T.D. Arief, N. Handayani, P. Sawitri, J.Teknik Sipil, 1, hal. 1-8, Universitas Kriten Petra, Surabaya (2001) (Indonesian)

12. T.P.M. Panjaitan, B. Pramudya, Manuwoto, I.F.P. Poerwo, J. Sabuga, 1, hal. 1-8, PWK, Universitas Sam Ratulangi, Manado (2011) (Indonesian)

13. Syaiful, Syaiful, Analisis kebisingan arus lalu lintas dan geometri jalan di kawasan simpang lima kota Semarang. Masters thesis, program Pascasarjana Universitas Diponegoro, Diponegoro University, Semarang: INSTITUTIONAL REPOSITORY Available : http://eprints.undip.ac.id/13253/ (2005) (Indonesian)

14. Syaiful, I.J.A.R, 4, pp. 772-779, Available: http://www.journalijar.com/article/7687/ (2016)

15. Syaiful, Syaiful, Y. Elvira, I.J.T.I, 1, pp. $34 \quad$ - 40, Available: http://jurnal.narotama.ac.id/index.php/ijti (2017) 